НАУКОВИЙ ВІСНИК

cientific messenger of Lviv National University

.

TIIIT

1. 4 At

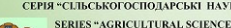

Том 22 № 93 2020
Науковий вісник Дьвівського національного університету ветеринарної медицини та біотехнологій імені С.3. Гжицького. Серія: Сільськогосподарські науки

Scientific Messenger of Lviv National University of Veterinary Medicine and Biotechnologies. Series: Agricultural sciences

UDC 636:575.16:591

\title{
Modern achievements of the development of scientific research at obtaining in vitro sheep embryos
}

\author{
O. M. Sharan, V. Yu. Stefanyk, S. G. Shalovylo
}

Stepan Gzhytskyi National University of Veterinary Medicine and Biotechnologies Lviv, Ukraine

Article info

Received 24.08.2020

Received in revised form 23.09.2020

Accepted 24.09.2020

Stepan Gzhytskyi National University of Veterinary Medicine and Biotechnologies Lviv,

Pekarska Str., 50, Lviv, 79010, Ukraine.

Tel.: +38-093-762-09-72

E-mail: oshaom737@gmail.com
Sharan, O. M., Stefanyk, V. Yu., \& Shalovylo, S. G. (2020). Modern achievements of the development of scientific research at obtaining in vitro sheep embryos. Scientific Messenger of Lviv National University of Veterinary Medicine and Biotechnologies. Series: Agricultural sciences, 22(93), 60-68. doi: 10.32718/nvlvet-a9311

New literature data on research aimed at improving the in vitro production of sheep embryos presents in the article. An analysis of the achievements of scientists from different countries to increase the efficiency of the main stages of embryo production in vitro: maturation of oocytes in vitro, their in vitro fertilization and in vitro embryo culture. In the literature experience has shown that the efficiency of oocyte maturation in vitro is significantly influenced by the experience and qualifications of scientists, the age of the egg donor, the improvement of the environment by adding roscovitin to inhibit meiosis, $\alpha$-linolenic acid, cerium dioxide nanoparticles ( $\mathrm{CeO} 2 \mathrm{NPS}$ ) and sericin to accelerate nuclear maturation and increase the number of oocytes of the second meiotic metaphase (MII). The main factors influencing the effectiveness of in vitro fertilization have been identified, and the parameters of the limited time of fertilization ability of sperm and the ability of oocytes to fertilize, which is called the "fertile span", have been determined. The main effective medium that increases the effectiveness of in vitro fertilization - synthetic oviduct fluid (SOF) with the addition of heparin and serum of cattle or sheep. The main parameters of sheep embryo culture in vitro are presented with the definition of the most commonly used media and their influence on embryonic development. Potential ways to improve the production of sheep embryos in vitro with the determination of morphological evaluation of categories of oocytes, methods of synchronization of their maturation in vitro are also highlighted. At the same time, literature data on the synchronization of oocyte-cumulus complexes with the use of a large number of inhibitors of meiotic division are presented, which according to many scientists may be a key factor in improving the efficiency of sheep embryo production in vitro. In addition, the results of studies of many scientists on the expansion of the fertile gap of oocytes of sheep cultured in vitro using certain biologically active substances were analyzed. In conclusion, the prospect of using the technology of in vitro production of sheep embryos in biomedical research is highlighted.

Key words: embryo, oocyte, sheep, in vitro maturation, fertilization, culture.

\section{Сучасні досягнення розвитку наукових досліджень 3 отримання in vitro ембріонів овець}

О. М. Шаран, В. Ю. Стефаник, С. Г. Шаловило

Львівський національний університет ветеринарної медицини та біотехнологій імені С. 3. Гжицького, м. Львів, Україна

У статті наведено нові літературні дані щодо досліджень з удосконалення виробництва іп vіtro ембріонів овець. Проаналізовано досягнення науковців різних країн з підвищення ефективності основних етапів продукиї ембріонів іп vітrо: дозрівання оочитів in vitro, ̈̈х запліднення in vitro та культивування ембріонів in vitro. У джерелах літератури експериментально доведено, щуо на ефективність дозрівання оочитів іп vitro значний вплив мають досвід і кваліфікачія науковиів, вік донора яйцеклітини, поліпиення середовища додаванням росковітину для гальмування мейозу, $\alpha$-лінолевої кислоти, наночастинок діоксиду иерію (СеО 2 NРs) та серицину для прискорення ядерного дозрівання $і$ збільшення кількості ооцитів другої мейотичної метафази (МІІ). Встановлено 
основні чинники, які впливають на результативність запліднення in vitro, визначено параметри обмеженого часу запліднювальноі здатності спермїв і здатності ооцитів до запліднення, який називають “фертильним проміжком”. Визначено основне ефективне середовище, яке підвищує результативність запліднення іп vitro - синтетична яйцепровідна рідина (SOF) з додаванням гепарину та сироватки великої рогатої худоби або овець. Наведено основні параметри культивування ембріонів овець іп vіто з визначенням найбільш вживаних середовищ та їх вплив на ембріональний розвиток. Також висвітлено потениійні шляхи поліпиення продукиї ембріонів овець in vitro з визначенням за морфологічною очінкою категорій ооцитів, методів синхронізачї їх дозрівання іп vitro. Водночас наведено літературні дані щзодо синхронізації ооичт-кумулюсних комплексів з використанням великої кількості інгібіторів мейотичного поділу, щзо, на думку багатьох вчених, може бути ключовим чинником для підвищення ефективності виробництва ембріонів овець іn vitro. Крім того, проаналізовано результати досліджень багатьох науковців з розширення фертильного проміжку оочитів овець культивованих іп vitro використанням окремих біологічно активних речовин. На завершення висвітлена перспектива використання технології виробництва іп vitro ембріонів овець у біомедичних дослідженнях.

Ключові слова: ембріон, оочит, вівчя, іп vіtro дозрівання, запліднення, культивування.

\section{Ветуп}

Біотехнологія розмноження овець розпочала нову еру в 1986 році з першого успішного запліднення in vitro (IVF - in vitro fertilization) в Кембриджі (Великобританія) (Cheng et al., 1986). До кінця 1980-х років запліднення in vitro набуло поширення і отримало назву “виробництво ембріонів in vitro" (in vitro embryo production - IVP), яке включає три процедури: дозрівання in vitro - in vitro maturation (IVM), запліднення in vitro - in vitro fertilization (IVF) та культивування ембріонів in vitro - in vitro embryo culture (IVC). Від 90-х років минулого століття до сьогодні продукція ембріонів in vitro 3 використанням трьох вказаних вище процедур постійно удосконалюється і $є$ важливим інструментом для з'ясування особливостей раннього розвитку ссавців, лікування порушень відтворювальної функції людини, збереження гамет і ембріонів тварин 3 високими генетичними якостями (Rizos et al., 2008) та прискорення генетичного вдосконалення поголів'я тварин.

Однак продукція ембріонів in vitro у овець не досягла високої ефективності: приблизно 70-90% незрілих яйцеклітин дозрівають від профази I до метафази II; 50-80 \% запліднюються і діляться до двоклітинної стадії через 24-48 год після осіменіння; лише 20-50 \% незрілих яйцеклітин досягають стадії бластоцисти (Walker et al., 1996). Крім того, ембріони, отримані in vivo, мають вищу якість, ніж ембріони, отримані in vitro, що підтверджується вищими показниками імплантації, якістю новонароджених та їх виживанням. Це створює передумови для удосконалення основних процедур виробництва ембріонів овець in vitro.

За повідомленням Продовольчої та сільськогосподарської організації ООН (ФАО), поголів'я овець у світі збільшилось з 1060 млн у 2000 році до 1196 млн голів у 2014 році (цитовано за даними FAOSTAT, 2017).

Ця тенденція свідчить про те, що виробництво ембріонів in vitro як нова репродуктивна технологія може відігравати важливу роль для створення овець у майбутньому та підвищення ефективності виробництва продукції вівчарства. Хоча виробництво ембріонів in vitro супроводжується багатьма технічними проблемами (низька ефективність технології та низька якість ембріонів), воно залишається важливим, особливо для підвищення генетичного потенціалу овець порівняно $з$ природним розмноженням і може бути використане для забезпечення сталого розвитку вів- чарства. Водночас останнім часом появилося багато позитивних відгуків щодо виробництва ембріонів in vitro в овець (Cognié et al., 2003; Cox \& Alfaro, 2007; Amiridisa \& Cseh, 2012; De Souza-Fabjan et al., 2014; Paramio \& Izquierdo, 2016; Botigelli et al., 2017), у яких не лише описано досягнення в галузі, а й вказано напрям технології на майбутнє.

У зв'язку з наведеним вище представляємо узагальнені сучасні досягнення та проблеми продукції ембріонів in vitro у овець, пропонуємо можливі підходи до вирішення проблем, а також прогноз щодо перспективи застосування систем IVP овець, особливо в біомедичних дослідженнях.

\section{Результати та їх обговорення}

Важливу увагу дослідники приділяють дозріванню ооцитів овець in vitro. Незрілим ооцитам для запліднення варто забезпечити цитоплазматичне та ядерне дозрівання, потім 3'являється перше полярне тільце і вони вступають у метафазу II, очікуючи запліднення (Cognié et al., 2003). Тому дозрівання in vitro (IVM) $є$ ключовим кроком до забезпечення якісних яйцеклітин для запліднення in vitro (IVF) та визначає потенційну здатність ооцитів до розвитку. Тобто, необхідною умовою отримання здорового ембріона $є$ отримання яйцеклітини хорошої якості. Наприклад, невідповідне дозрівання in vitro ооцитів $\epsilon$ основною причиною поліспермії після IVF порівняно 3 компетентністю розвитку ооцитів, отриманих in vivo та in vitro (Maalouf et al., 2009).

За останні роки науковцями різних країн світу досягнуто значного прогресу дозрівання ооцитів (IVM) овець (Ledda et al., 2016; Crocomo et al., 2016). Зокрема, основним середовищем дозрівання, що використовується у більшості лабораторій, є тканинне культуральне середовище ТСМ 199 (Tissue Culture Medium 199), доповнене 10 \% сироваткою, включаючи фетальну сироватку великої рогатої худоби, сироватку овець, бичачий сироватковий альбумін (БСА) Bovine serum albumin (BSA), фолікулярну рідину. Також в середовище дозрівання додають гормони: фолікулостимулюючий гормон - (ФСГ) або комбінацію ФСГ з лютеїнізуючим гормоном (ЛГ) чи $17 \beta$ естрадіолом. Водночас умови дозрівання яйцеклітин овець в умовах in vitro є стандартними: $38,5-39^{\circ} \mathrm{C}$, $5 \% \mathrm{CO}_{2}$ впродовж 20-24 год.

Оскільки дозрівання in vitro ооцитів розроблено та виконується дослідниками, істотний вплив на успіх IVP овець має досвід і кваліфікація науковців. Зокре- 
ма, однією з багатьох причин, які можуть впливати на результати дослідження, є різний досвід дослідників. Досвідчений дослідник забезпечує якісний відбір ооцитів, а також короткий термін між аспірацією ооцитів 3 фолікулів яєчників та культивуванням їх у середовищі для дозрівання. Крім того, досвідчені дослідники обробляють ооцити швидше, ніж початківці. Коротший час поводження 3 ооцитами означає, що ооцит-кумулюсні комплекси (ОКК) будуть більш синхронізовані, оскільки фізичне видалення ОКК 3 фолікулів яєчників призводить до спонтанного відновлення мейозу, викликаючи асинхронність між цитоплазматичним та ядерним дозріванням і знижує компетентність розвитку ооцитів. Таким чином, для успіху IVP овець необхідним і важливим є належне навчання для початківців, водночас командна робота також є вирішальною для прискорення роботи з ооцитами для IVM.

Відомо, що розмноження овець залежить від сезону статевої активності. У зв'язку з цим у більшості лабораторій спостерігається періодичне зниження результативності отримання ембріонів - ймовірно, сезон впливає на якість ооцитів. Дослідженнями автоpiв (Mara et al., 2014) на основі аналізу роботи з IVP впродовж трьох років проведено оцінку впливу сезону на кількість бластоцист та ягнят, одержаних in vitro. Були визначені середовища для дозрівання та культивування ембріонів: ТСМ199 + БСА та синтетична рідина з амінокислотами - Synthetic Oviduct Fluid amino acids (SOFaa) + БСА відповідно. Дозрілі ооцити запліднювали свіжою спермою в синтетичній яйцепровідній рідині (SOF) з $20 \%$ інактивованою високою температурою естральною сироваткою овець. Результатами не встановлено суттєвих відмінностей у показниках поділу ембріонів залежно від сезону впродовж трьох років, хоча стадія бластоцисти вірогідно змінювалася між сезонами в окремі роки (Р < 0,05-0,001). Крім того, не було відмінностей у вагітності та народженні ягнят між ембріонами анестрального періоду порівняно з сезоном розмноження. Тому автори дійшли висновку, що сезонність впливає лише на стадію розвитку бластоцисти (Mara et al., 2014).

Аналогічний експеримент in vivo проведено для з'ясування впливу сезону на суперовуляцію у вівцематок породи саффолк, зокрема на швидкість овуляції та якість ембріонів (Shi et al., 2015). У результаті експерименту встановлено, що рівень овуляції у вівцематок був вищим в анестральний період, тимчасом як життєздатність ембріонів була більшою у парувальний сезон. Хоча між двома періодами статевої активності не спостерігали суттєвої різниці у приживленні трансплантованих ембріонів та кількості нащадків на одного донора, проте співвідношення кількість ягнят / яйцеклітини вівцематок-донорів, суперовульованих в анестральний період, було нижчим (P <0,01). Ці результати підтверджують сезонний вплив на якість ооцитів у вівцематок, що може частково пояснити причини різної ефективності IVP овець впродовж сезонів статевої активності.

У багатьох публікаціях вказується, що, крім сезонної активності, вік донора яйцеклітини є важливим чинником, який впливає на компетентність розвитку ооцита, хоча ооцити, отримані від ярок, здатні розвивати здорове потомство після трансплантації ембріонів. Так, Kochhar та ін. (Kochhar et al., 2001) спостерігали, що ооцити, отримані від ярок, досягали другої мейотичної метафази (MII) лише через 24 год (60,0\%) та 26 год (28,6\%), тимчасом як 85,7 \% ооцитів, отриманих від вівцематок, досягли стадії MII до 24 год дозрівання. Радіоактивне маркування ооцитарних білків виявило вищу інкорпорацію [(35) S -] - метіоніну та $[(35) \mathrm{S}]$-цистеїну в ооцити, отримані від вівцематок, порівняно з ооцитами від ярок. Водночас D. T. Armstrong (2001) вказував, що вікові відхилення ооцитів ярок включають: 1) мейотичну некомпетентність або неможливість завершити мейотичне дозрівання, що призводить до нездатності ооцитів до запліднення; 2) порушення в мейозі, які можуть бути сумісні з заплідненням, але призводять до генетичних відхилень, які знижують життєздатність ембріонів; 3) цитоплазматичні дефекти, які виражаються на декількох стадіях розвитку до запліднення або після нього.

Крім меншої стійкості до невідповідних умов, встановлено вірогідно нижчий показник $(\mathrm{P}<0,01)$ дроблення зигот 3 ооцитів ярок через 22 та 26 год після запліднення, тимчасом як на 32 год після запліднення він був вищим ( $<<0,01)$, ніж у ооцитів вівцематок. Аналогічну тенденцію спостерігали при формуванні бластоцист із запліднених in vitro ооцитів (Leoni et al., 2006). Наявні дані свідчать про те, що загалом ооцити від ярок-донорів та ембріони, отримані $з$ них, є менш стійкими до субоптимальних умов культивування in vitro, ніж ооцити від дорослих вівцематок.

Важливе значення для IVM має склад середовищ та використання біологічно активних речовин у їхньому складі. Майже у всі середовища для дозрівання ооцитів овець in vitro додавали або 10 \% сироватки, включаючи сироватку великої рогатої худоби (FCS Foetal calf serum, FBS - Foetal bovine serum), сироватку овець (SS - Sheеp serum, OSS або ESS - Oestrus sheep serum) та фолікулярну рідину (FF - Follicular fluid) або BSA (як визначене середовище). Незважаючи на невизначений і мінливий характер складу сироватки, сироватка крові та BSA $є$ одними 3 найпоширеніших компонентів середовища в системах культивування ооцитів та ембріонів ссавців. A. Shirazi et al. (2012) оцінювали вплив джерела білка (FBS та BSA) в середовищі для дозрівання на розвиток компетентності ооцитів овець. У результаті встановлено, що додавання FBS до середовища дозрівання може значно поліпшити кратність дроблення зиготи та загальної кількості бластоцист порівняно з дододаванням BSA. Однак на кріотолерантність бластоцист негативно впливала присутність FBS під час IVM. Варто зазначити, що не всі сироватки адаптуються до IVM ооцитів овець. Сироватку, яка використовується для IVM, зазвичай перевіряють серед декількох зразків сироваток у процесі IVP і відбирають найкращу.

У літературі є відомості про експерименти, в яких дослідники намагалися поліпшити IVM ооцитів овець. Зокрема, для перевірки гіпотези мейотичного гальмування в середовище дозрівання додавали рос- 
ковітин - інгібітор циклінозалежних кіназ. ОКК овець культивували впродовж 6 год у присутності 75 мкм росковітину (дослід) або без нього (контроль), згодом ïx піддавали IVM впродовж 18 год у присутності гонадотропінів, а потім IVF та IVC. У результаті встановлено, що за використання росковітину висока частка ооцитів $(93,6 \%)$ досягла стадії MII після IVM, тимчасом як у контролі лише 88,4 \%. Як у досліді, так i в контролі приблизно $70 \%$ ооцитів поділилися i $50 \% 3$ них розвинулися до бластоцист. Отже, росковітин ефективний для зворотного інгібування мейозу ооцитів дорослих овець без шкідливого впливу на розвиток та якість ембріонів, отриманих in vitro (Crocomo et al., 2016).

В інших дослідженнях до середовища дозрівання додавали $\alpha$-лінолеву кислоту - поліненасичену жирну кислоту, яка $є$ у високих концентраціях у фолікулярній рідині. Однак у низькій концентрації $\alpha$-лінолева кислота не справляла негативного впливу на компетентність розвитку ооцитів (Amini et al., 2016).

На відміну від цього додавання 200 мкМ $\alpha$ лінолевої кислоти до середовища IVM ооцитів ярок негативно впливало на ядерне дозрівання та розмноження кумулюсних клітин на відміну від концентрацій 50 і 100 мкМ. $\alpha$ - лінолева кислота поліпшила формування чоловічих пронуклеусів і якість бластоцист, проте не виявлено впливу на частоту поділу та утворення бластоцисти (Ghaffarilaleh et al., 2014). Отже, висока концентрація $\alpha$-лінолевої кислоти в середовищі дозрівання знижує швидкість дозрівання та згодом здатність ооцитів овець до розвитку, проте не з'ясована їі функція за високої концентрації фолікулярної рідини.

F. Ariu et al. (2017) з'ясовували, чи впливають наночастинки діоксиду иерію (CеO2 NPs) під час дозрівання in vitro (IVM) ооцитів ярок на їх ембріональний розвиток in vitro. ОКК, отримані з яєчників ярок після забою, піддавали IVM 3 CeO2 NPs $(0,44,88$ або 220 мкг/мл), потім дозрілі яйцеклітини запліднювали in vitro, а зиготи культивували впродовж 7 діб. У результаті встановили, що $\mathrm{CeO} 2$ NPs у концентрації 44 мкг/мл значно підвищили вихід бластоцист, а також внутрішню клітинну масу та кількість клітин трофоектодерми. Отже, CeO2NPs у низьких концентраціях в середовищі дозрівання збільшує продукцію in vitro ембріонів з ооцитів ярок.

В окремих дослідженнях вивчався вплив серищину, який $є$ одним 3 головних компонентів тутового шовкопряда (Mara et al., 2014). Експериментально доведено, що серицин $\mathrm{S}$ може покращити безсироваткову культуру клітин ссавців (Sasaki et al., 2005). В експерименті F. Aghaz et al. (2015) 0,1 \% i 0,5 \% серицину додавали в середовище для IVM, зрілі ооцити запліднювали свіжою спермою, а зиготи культивували in vitro. У результаті встановлено, що додавання 0,1 \% та 0,5\% серицину під час IVM суттєво впливає на ядерне та цитоплазматичне дозрівання і поліпшує передімплантаційний розвиток ембріонів овець, культивованих in vitro (Aghaz et al., 2015). Аналогічні результати отримані Yasmin C. et al. (2015). Отже, білок серицин може бути використаний для IVM яйцеклітин овець. Крім того, були спроби поліпшення дозрівання ооцитів овець додаванням інсулінутрансферину-селену та аскорбінової кислоти в середовище дозрівання (María-Gracia et al., 2013), проте вони не були успішними. Отже, впродовж останніх років було досягнуто прогресу в IVM яйцеклітин овець. Однак, порівняно з ефективністю IVM яйцеклітини овець, досягнутою S. K. Walker et al. (1996) два десятиліття тому, ефективність сьогодні майже однакова, якщо її вимірювати формуванням бластоцисти.

На відміну від IVM, у процесі запліднення in vitro (IVF) беруть участь як ооцити, так і спермії. Водночас ооцити та спермії залежать від часу, тобто спермії мають обмежений час запліднювальної здатності, а ооцити - здатність до запліднення. Цей обмежений час ооцитів та сперміїв називають “фертильним проміжком”. Тривалий або короткий фертильний проміжок значною мірою залежить від багатьох чинників, таких як порода, сезон, вік і годівля донора, якість гамет, середовище та умови зберігання, включаючи значення $\mathrm{pH}$, осмолярність, компоненти, гази тощо. Фертильний проміжок гамет мінливий навіть у одних i тих же особин, тому для успішного IVF дуже важливі терміни. Ооцити та спермії повинні спільно інкубуватися у межах їх фертильного проміжку, щоб забезпечити запліднення максимальної кількості зрілих ооцитів відповідними капацитованими сперміями.

Загалом запліднення in vitro відбувається після 2024 год IVM, коли більшість ооцитів у середовищі дозрівання вже досягли метафази другого мейотичного поділу (МII). У більшості лабораторій використовують деконсервовані спермії, водночас окремі лабораторії вважають за краще використовувати свіжу сперму, якщо вона $є$. Найпоширенішим середовищем запліднення ооцитів овець $є$ середовище SOF Synthetic Oviduct Fluid (Синтетична яйцепровідна рідина), доповнене гепарином 1-2 мкг/мл + 2-20\% сироватки великої рогатої худоби або овець (FCS, FBS або SS).

Незалежно від інших умов за IVF ооцитів із додаванням $2 \%$ сироватки кількість сформованих бластоцист становило від $20 \%$ до 59,2\%, тимчасом як за додавання $20 \%$ сироватки - від 24,1\% до $42 \%$. Варто зазначити, що ооцити овець, запліднені в середовищі $\mathrm{SOF}+2 \%$ сироватки крові, краще розвивалися до стадії бластоцисти, ніж ті, що розвивалися в середовищі SOF 3 додаванням $20 \%$ сироватки. Аналогічно за умов IVF ооцитів кози отримали подібні результати - за додавання $2 \%$ естральної сироватки овець (ESS Oestrus sheep serum) досягли кращих результатів, ніж без використання сироватки або за додавання стандартної 20 \% концентрації (López-Saucedo et al., 2013). Отже, висока концентрація сироватки, очевидно, сприяє збільшенню поліспермії в запліднених ооцитах i зменшує кількість нормальних ембріонів. Варто зазначити, що не всі сироватки придатні для IVF ооцитів овець, а тому відповідну сироватку потрібно випробувати і відібрати для успішного запліднення in vitro ооцитів овець.

Порівняно з IVM та IVF, тривалість культивування ембріонів значно довша - 6-8 діб. Тому культуральне середовище $\epsilon$ надзвичайно важливим для розвитку ембріонів in vitro. Як IVM та IVF, так і процедура 
культивування ембріонів овець in vitro істотно не змінилися в більшості лабораторій світу за понад два десятиліття. Зиготи овець культивують у синтетичній яйцепровідній рідині (SOF) 3 додаванням амінокислот та BSA. Це поєднання є стандартним або звичайним базовим культуральним середовищем для ембріонів овець. Для зниження можливості окиснення концентрацію кисню підтримують на рівні $5 \%\left(5 \% \mathrm{O}_{2}, 5 \%\right.$ $\mathrm{CO}_{2}, 90 \% \mathrm{~N}_{2}$ ).

Формування бластоцисти відбувається на 6-8 добу культивування. Під час культивування ембріонів культуральне середовище зазвичай змінюють кожні 48 год або застосовують двоступеневе культивування, a саме: перші три доби ембріони культивують в SOFaa + BSA, а на 4 добу вони переносяться в SOFaa + глюкоза + сироватка овець / BPX або BSA і культивуються в середовищі до 8-ої доби.

Очевидно, в процесі культивування ембріонів впродовж тривалого часу створюються невідповідні умови для окремих ембріонів, що може спричинити епігенетичні зміни геномного імпринтингу та призвести до аномалій розвитку. Так, C. Schwarzer et al. (2012) встановили, що 13 різних протоколів культивування ембріонів призводять до чітко виражених клітинних та молекулярних фенотипів у мишачих ембріонів, що дозволяє припустити, що певні компоненти культурального середовища можуть перешкоджати епігенетичній регуляції генів. Дослідження ембріонального геному свідчать, що умови розвитку ембріонів in vitro сьогодні не можуть повністю імітувати in vivo умови експресії мРНК (Sadeesh et al., 2016). Крім того, R. Fernández-Gonzalez et al. (2004) спостерігали, що експресія мРНК деяких імпрексуючих генів суттєво порушена в бластоцистах, культивованих у присутності FCS. Є багато доказів, що певні компоненти середовища можуть впливати на епігенетичну регуляцію генів. Хоча додавання сироватки в культуральне середовище ембріона овець може призвести до високого ризику “синдрому великоплідності”, якщо ембріони будуть трансплантовані реципієнтам, проте, багато лабораторій вважають за краще використовувати іiі, оскільки збільшується кількість бластоцист (Khosla et al., 2001).

Однак в експерименті D. K. Gardner et al. (1994) показано, що бластоцисти овець після культивування у безсироватковому середовищі SOF за додавання амінокислот були значно більші і кількість клітин у бластоцисті значно збільшувалася при оновленні середовища кожні 48 год для зменшення токсичності амонію. Водночас незамінні амінокислоти та глютамін також значно зменшили кількість дегенерованих ембріонів (P < 0,05). Автори також спостерігали, що культивування ембріонів поодиноко або групами в середовищах SOF та Eagle's з амінокислотами, що оновлювалися кожні 48 год, призвело до значного збільшення вилуплення бластоцист.

Таким чином, невідповідні умови культиивування in vitro, що застосовуються сьогодні, впливають не тільки на швидкість ділення, утворення бластоцист та середню кількість клітин у бластоцисті під час культивування ембріонів, а й на рівень вагітності, розвиток плоду та вагу молодняку після народження і на- віть на стан здоров'я нащадків після трансплантації ембріонів. Тому оптимізацію культуральних середовищ для ембріонів овець потрібно здійснювати так, щоб якість ембріонів овець, отриманих in vitro, була наближена до якості in vivo.

Після дозрівання in vitro популяцію ооцитів можна умовно розділити на три субпопуляції, а саме: 1) дегенеровані ооцити, 2) незрілі ооцити, включаючи ядерні зрілі, але незрілі цитоплазматичні ооцити, 3) зрілі ооцити, включаючи запліднені та старі ооцити. Дегенеровані ооцити можна легко ідентифікувати та видалити, тимчасом як інші важко відрізнити один від одного до IVF. Тому важливим чинником для підвищення ефективності IVP овець $є$ збільшення популяції запліднених ооцитів та мінімізація інших ооцитів. Якщо ооцити синхронізовані на початку дозрівання in vitro, то популяція запліднених ооцитів значно збільшиться і підвищиться ефективність IVP. Встановлено, що фізичне видалення ОКК ссавців 3 фолікулів яєчників призводить до спонтанного відновлення мейозу значною мірою через зниження концентрації циклічного аденозинмонофосфату (цАМФ), викликаючи асинхронність між цитоплазматичним та ядерним дозріванням і зниженням здатності до розвитку ооцитів (Rose et al., 2013).

Очевидно, що дві асинхронності можуть сильно вплинути на ефективність IVP овець: 1) асинхронність цитоплазматичного та ядерного дозрівання в окремих ооцитах, 2) асинхронність серед ооцитів на стадіях розвитку. Першу асинхронність можна вдосконалити оптимізацією системи дозрівання ооцитів овець in vitro.

Асинхронність серед яйцеклітин на початку ооцитів впливає не тільки на швидкість дозрівання, а й згодом на здатність ооцитів до розвитку. Іноді фертильний проміжок може змінюватись залежно від якості ооцитів - старі або низької якості можуть мати коротший фертильний проміжок. Тобто, деякі ооцити МII можуть втратити здатність до запліднення in vitro, що матиме більше значення, коли ооцити відбирають у вівцематок в анестральний період або від ярок. Це дозволяе припустити, що “синхронізація” ооцитів на початку дозрівання in vitro може бути ключовим чинником для підвищення ефективності IVP овець (Aktas et al., 1995; Hashimoto et al., 2002; Coticchio et al., 2015). Сьогодні для цієї мети доступно багато інгібіторів, таких як циклогексимід (CHX) (German et al., 2015), інгібітор білкового синтезу, росковітин, потужний інгібітор кіназної активності, який стимулює Мфазу (MPF) (Crocomo et al., 2015), 6диметиламінопурин (6-DMAP) інгібітор фосфорилювання (Lonergan et al., 1997; Avery et al., 1998; Mermillod et al., 2000; Dode \& Adona, 2001) ванадат (NaV03), інгібітор протеїнтирозин фосфатаз (Lonergan et al., 1997), інвазивна позаклітинна аденілатциклаза (iAC) (Aktas et al., 1995), фосфодиестераза (PDE) інгібітор (IBMX) (Thomas et al., 2004; Buell et al., 2015), бутиролактон I, інгібітор ядерного дозрівання (Aktas et al., 1995; Ferreira et al., 2009). Однак результати виявили суперечливий вплив цих інгібіторів на зупинку мейотичного клітинного циклу, швидкість дозрівання і пізніше на потенціал розвитку. Крім того, 
деякі інгібітори, такі як СНХ, позитивно впливають на зупинку мейотичного клітинного циклу впродовж 24 год і на потенціал розвитку ооцитів окремих видів, включаючи свиней та велику рогату худобу (Saeki et al., 1997; Marques et al., 2011). Отже, використання інгібіторів може не тільки підвищити IVP овець, а й забезпечити транспортування ооцитів на велику відстань та гнучкий час початку IVM ооцитів.

“Синхронізація” ооцитів овець за культивування in vitro може поліпшити їхню якість та збільшити кількість ооцитів MII, здатних до запліднення або активації в аналогічний період IVM. Однак фертильний проміжок для окремих оцитів MII може змінюватись залежно від багатьох чинників, таких як порода, вік, пора року, годівля, репродуктивні показники, клімат (світло, температура, вологість), а також протокол, що використовується для IVM та ще таких умов, як середовище, технічні навички, газовий склад тощо.

Крім того, запліднення має відбуватися в час, коли більшість ооцитів MII досягли початку свого фертильного проміжку, щоб спермії могли проникати та запліднювати ооцити до моменту їх старіння. Отже, час запліднення ооцитів МII $€$ надзвичайно важливими для забезпечення подальшого розвитку ембріона. Однак окремі ооцити можуть мати різний фертильний проміжок, який може змінюватись залежно від їхньої якості. Тому порівняно $з$ ооцитами in vivo дозрілі in vitro ооцити можуть мати коротший фертильний проміжок. Це може частково пояснити, чому ооцити після IVF можуть мати високу швидкість розщеплення i водночас низьку швидкість формування бластоцисти. Виходячи з цього постає питання, чи можна розширити фертильний проміжок в ооцитах IVM, щоб гарантувати достатньо часу для проникнення та запліднення якісних ооцитів?

Дослідженням J. Zhu et al. (2015) встановлено, що можна розширити фертильний проміжок в ооцитах щурів, оброблених демеколцином. Подібні експерименти проводили I. Choi et al. (2010) 3 ооцитами овець. Спочатку ооцити овець обробляли впродовж 10 год 10 мМ кофеїном, а потім їх використовували як енуклейовану цитоплазму реципієнтна для перенесення ядер соматичних клітин. У результаті встановлено, що енуклейовані цитопласти, оброблені кофеїном впродовж 6 год, можуть поліпшити перепрограмування соматичної клітини після somatic cell nuclear transfer (SCNT), що призвело до народження SCNT здорового ягняти. Крім того, у запліднених in vitro ооцитів спостерігається підвищена частота поліспермії та фрагментації, зменшення частоти розщеплення та зменшення частоти розвитку до стадії бластоцисти.

Цікаво, що обробка ооцитів овець кофеїном $10 \mathrm{мM}$ з 18 по 24 год після дозрівання може підвищити активність як maturation-promoting factor (MPF), так i mitogen-activated protein kinase (MAРК) в ооцитах MII, тимчасом як обробка ооцитів МII від 24 до 30 год після дозрівання 10мМ кофеїном може запобігти зниженню MPF та MAPK (Lee \& Campbell, 2006). Іншими словами, ооцити МII овець, оброблені кофеїном, можуть мати тривалий фертильний період. Крім того, W.E. Maalouf et al. (2009) встановлено, що денудовані ооцити овець, оброблені 10 мМ кофеїном, мали вищу швидкість розвитку до бластоцисти, але не впливали на якість бластоцист.

Фактор, що сприяє дозріванню - maturation promoting factor (MPF), відповідає за зупинку мейотичного клітинного циклу ооцитів МII. Тому підтримка MPF в ооцитах MII овець на високому рівні $є$ важливим для цієї мети. Існує кілька інгібіторів, таких як кофеїн, демекольцин, нокадазон та MG-132, які ефективно блокують відновлення мейотичних ооцитів у різних видів тварин (Choi et al., 2010).

Усі результати свідчать про те, що час для оптимального запліднення можна розширити. Водночас варто зазначити, що обробка кофеїном ооцитів миші може спричинити затвердіння zona pellucida, що знижує швидкість формування бластоцист (Zhang et al., 2017). Це свідчить про те, що обробка ооцитів кофеїном може спричинити певні побічні ефекти на потенціал їх розвитку. Тому потрібне подальше дослідження впливу інгібіторів на ооцити овець, а також розроблення нової ідеї або стратегії для вирішення найважливіших питань IVP овець, щоб у найближчому майбутньому підвищити іï ефективність.

В останнє десятиліття вівці $є$ не тільки цінними тваринами, які виробляють м'ясо, молоко, вовну i шкіру для людей, а також стають важливою моделлю для використання в біомедичних дослідженнях для імітації захворювань людини. Порівняно 3 великою рогатою худобою вівці більше підходять як модель тварини з оптимальними розмірами, легкістю в роботі, коротким репродуктивним циклом та економічною ефективністю. До того ж вівці мають подібну до людей картину захворювань, включаючи алергічний риніт, синусит та поліпоз носа. До інших переваг можна віднести їхню толерантність до тривалих хірургічних процедур та велику порожнину носа, що робить їх придатними для ендоскопічної хірургії синуситів (Shin, 2016). Тому використання овець як моделей може стати новою силою, яка стимулюватиме розвиток IVP овець, що сприятиме підвищенню ефективності ведення вівчарства та біомедичних досліджень.

\section{Висновки}

Таким чином, удосконалення системи IVP овець було повільним впродовж останніх 5 років, ефективність залишається низькою і суттєвого прогресу не досягнуто. Водночас потреби виробництва вівчарської продукції у світі та моделей овець для використання в біомедичних дослідженнях швидко виросли, що створює можливість для підвищення ефективності IVP овець.

\section{References}

Aghaz, F., Hajarian, H., Shabankareh, H. K., \& Abdolmohammadi, A. (2015). Effect of sericin supplementation in maturation medium on cumulus cell expansion, oocyte nuclear maturation, and subsequent embryo development in Sanjabi ewes during the breeding season. Theriogenology, 84(9), 1631-1635. doi: $10.1016 /$ j.theriogenology.2015.08.013. 
Aktas, H., Wheeler, M. B., First, N. L., \& Leibfried Rutledge, M. L. (1995). Maintenance of meiotic arrest by increasing [cAMP]i may have physiological relevance in bovine oocytes. J. Reprod. Fertil, 105, 237-45. doi: 10.1530/jrf.0.1050237.

Amini, E., Asadpour, R., Roshangar, L., \& Jafari-joozani, R. (2016). Effect of $\alpha$-linoleic acid supplementation on in vitro maturation, embryo development and apoptotic related gene expression in ovine. Int. J. Reprod. Biomed (Yazd), 14(4), 255-262. URL: https://www.ncbi.nlm.nih.gov/pmc/articles/PMC4918 772.

Amiridisa, G. S., \& Cseh, S. (2012). Assisted reproductive technologies in the reproductive management of small ruminants. Anim Reprod Sci, 130(3-4), 152-161. doi: 10.1016/j.anireprosci.2012.01.009.

Ariu, F., Bogliolo, L., Pinna, A., Malfatti, L., Innocenzi, P., Falchi, L., Bebbere, D., \& Ledda, S. (2017). Cerium oxide nanoparticles (CeO2 NPs) improve the developmental competence of in vitro-matured prepubertal ovine oocytes. Reprod Fertil Dev, 29(5), 1046-1056. doi: 10.1071/RD15521.

Armstrong, D. T. (2001). Effects of maternal age on oocyte developmental competence. Theriogenology, 55(6), 1303-1322. doi: 10.1016/s0093-691x(01)00484-8.

Avery, B., Hay-Schmidt, A., Hyttel, P., \& Greve, T. (1998). Embryo development, oocyte morphology, and kinetics of meiotic maturation in bovine oocytes exposed to 6-dimethylaminopurine prior to in vitro maturation. Mol. Reprod. Dev, 50(3), 334-344. URL: https://pubmed.ncbi.nlm.nih.gov/9621310.

Botigelli, R. C., Razza, E. M., Pioltine, E. M, \& Nogueira, M. F. (2017). New approach regarding the in vitro maturation of oocytes: manipulating cyclic nucleotides and their partners in crime. JBRA Assisted Reprod, 21(1), 35-44. doi: 10.5935\%2F1518-0557.20170010.

Buell, M., Chitwood, J. L., \& Ross, P. J. (2015). cAMP modulation during sheep in vitro oocyte maturation delays progression of meiosis without affecting oocyte parthenogenetic developmental competence. Anim. Reprod. Sci., 154, 16-24. doi: 10.1016/j.anireprosci.2014.12.012.

Cheng, W. T. K., Moor, R. M., \& Polge, C. E. (1986). In vitro fertilization of pig and sheep oocytes matured in vivo and in vitro. Theriogenology, 25, 14. URL: https://ci.nii.ac.jp/naid/10020372647.

Choi, I., Lee, J. H., Fisher, P., \& Campbell, K. H. (2010). Caffeine treatment of ovine cytoplasts 661 regulates gene expression and foetal development of embryos produced by somatic cell nuclear transfer. Mol. Reprod. Dev., 77(10), 876-887. doi: 10.1002/mrd.21230.

Cognié, Y., Baril, G., Poulin, N., \& Mermillod, P. (2003). Current status of embryo technologies in sheep and goat. Theriogenology, 59(1), 171-188. doi: 10.1016/s0093-691x(02)01270-0.

Coticchio, G., Dal Canto, M., Mignini Renzini, M., Guglielmo, M. C., Brambillasca, F., \& Turchi, D. (2015). Oocyte maturation: gamete-somatic cells interactions, meiotic resumption, cytoskeletal dynamics and cytoplasmic reorganization. Hum. Reprod Update, 21(4), 427-454. doi: 10.1093/humupd/dmv011.
Cox, J. F., \& Alfaro, V. (2007). In vitro fertilization and development of OPU derived goat and sheep oocytes. Reprod. Domest Anim, 42(1), 83-87. doi: 10.1111/j.1439-0531.2006.00735.x.

Crocomo, L. F., Ariu, F., Bogliolo, L., Bebbere, D., Ledda, S., \& Bicudo, S. D. (2016). In vitro Developmental Competence of Adult Sheep Oocytes Treated with Roscovitine. Reprod. Domest. Anim., 51(2), 276-281. doi: 10.1111/rda.12677.

Crocomo, L. F., Ulian, C. M. V., da Silva Branchini, N., da Silva, D. T., Filho, W. C. M., da Cruz Landim Alvarenga, F., \& Bicudo, S. D. (2015). Meiotic arrest of sheep oocytes using roscovitine under different medium compositions Small Ruminant Res, 126, 5258. doi: 10.1016/j.smallrumres.2015.02.022.

De Souza-Fabjan, J. M. G., Panneau, B., Duffard, N., Locatelli, Y., De Figueiredo, J. R., De Figueirêdo Freitas, V. J., \& Mermillod, P. (2014). In vitro production of small ruminant embryos: late improvements and further research (a review). Theriogenology, 81(9), 1149-1162. doi: 10.1016/j.theriogenology.2014.02.001.

Dode, M. A., \& Adona, P. R. (2001). Developmental capacity of Bos indicus oocytes after 607 inhibitions of meiotic resuption by 6-dimethylaminopurine. Anim. Reprod. Sci., 65(3-4), 171-180. doi: 10.1016/s0378-4320(00)00207-4.

Dos Santos Neto, P. C., Vilariño, M., Barrera, N., Cuadro, F., Crispo, M., \& Menchaca, A. (2015). Cryotolerance of Day 2 or Day 6 in vitro produced ovine embryos after vitrification by Cryotop or Spatula methods. Cryobiology, 70(1), 17-22. doi: 10.1016/j.cryobiol.2014.11.001.

Fernández-Gonzalez, R., Moreira, P., Bilbao, A., Jiménez, A., Pérez-Crespo, M., Ramírez, M.A., Rodríguez, De Fonseca, F., Pintado, B., \& Gutiérrez-Adán, A. (2004). Long-term effect of in vitro culture of mouse embryos with serum on mRNA expression of imprinting genes, development, and behaviour. Proc Natl Acad Sci USA, 101(16), 5880-5885. doi: 10.1073/pnas.0308560101.

Ferreira, E. M., Vireque A. A., Adona, P. R., Ferriani, R. A., Navarro, P. A. (2009). Prematuration of bovine oocytes with butyrolactone I reversibly arrests meiosis without increasing meiotic abnormalities after in vitro maturation. Eur. J. Obst. Gynecol. Reprod. Biol. 145, 76-80. doi: 10.1016/j.ejogrb.2009.03.016.

García-Álvarez, O., Maroto-Morales, A., Ramón, M., Del Olmo, E., Jiménez-Rabadán, P., \& Fernández-Santos, M. R. (2014). Dynamics of sperm subpopulations based on motility and plasma membrane status in thawed ram spermatozoa incubated under conditions that support in vitro capacitation and fertilisation. Reprod Fertil Dev. 26(5), 725-732. doi: 10.1071/RD13034.

Gardner, D. K., Lane M., Spitzer A., Batt P.A. (1994). Enhanced rates of cleavage and development for sheep zygotes cultured to the blastocyst stage in vitro in the absence of serum and somatic cells: amino acids, vitamins, and culturing embryos in groups stimulate development. Biol Reprod, 50(2), 390-400. doi: 10.1095/biolreprod50.2.390.

German, S. D., Lee, J. H., Campbell, K. H., Sweetman, D., \& Alberio, R. (2015). Actin depolymerization is associated with meiotic acceleration in cycloheximide- 
treated ovine oocytes. Biol. Reprod, 92(4), 103. doi: 10.1095/biolreprod.114.122341.

Ghaffarilaleh, V., Fouladi-Nashta, A., \& Paramio, M. T. (2014). Effect of $\alpha$-linolenic acid on oocyte maturation and embryo development of prepubertal sheep oocytes. Theriogenology, 82(5), 686-696. doi: 10.1016/j.theriogenology.2014.05.027.

Hashimoto, S., Minami, N., Takakura, R., \& Imai, H. (2002). Bovine immature oocytes acquire developmental competence during meiotic arrest in vitro. Biol. Reprod, 66(6), 1696-1701. doi: 10.1095/biolreprod66.6.1696.

Hosseini, S. M., Asgari, V., Ostadhosseini, S., Hajian, M., Ghanaei, H. R., \& Nasr-Esfahani, M. H. (2015). Developmental competence of ovine oocytes after vitrification: Differential effects of vitrification steps, embryo production methods, and parental origin of pronuclei. Theriogenology, 83(3), 366-376. doi: 10.1016/j.theriogenology.2014.09.031.

Khosla, S., Dean, W., Reik, W., \& Feil, R. (2001). Culture of pre-implantation embryos and it long-term effects on gene expression and phenotype. Hum Reprod Update, 7(4), 419-427. doi: 10.1093/humupd/7.4.419.

Kochhar, H. P., Wu, B., Morris, L. H., Buckrell, B. C., Pollard, J. W., Basrur, P. K., \& King, W. A. (2001). Maturation status, protein synthesis and developmental competence of oocytes derived from lambs and ewes. Reprod Domest Anim, 37(1), 19-25. doi: 10.1046/j.1439-0531.2002.00326.x.

Ledda, S., Idda, A., Kelly, J., Ariu, F., Bogliolo, L., \& Bebbere, D. (2016). A novel technique for in vitro maturation of sheep oocytes in a liquid marble microbioreactor. J Assist Reprod Genet, 33(4), 513518. doi: 10.1007/s10815-016-0666-8.

Lee, J. H., \& Campbell, K. H. (2006). Effects of enucleation and caffeine on maturation- promoting factor (MPF) and mitogen-activated protein kinase (MAPK) activities in ovine oocytes used as recipient cytoplasts for nuclear transfer. Biol Reprod, 74(4), 691-698. doi: 10.1095/biolreprod.105.043885.

Leoni, G. G., Succu, S., Berlinguer, F., Rosati, I., Bebbere, D., Bogliolo, L., Ledda, S., \& Naitana, S. (2006). Delay on the in vitro kinetic development of prepubertal ovine embryos. Formation Anim Reprod Sci, 92(3-4), 373383. doi: 10.1016/j.anireprosci.2005.05.027.

Lonergan, P., Khatir, H., Carolan, C., \& Mermillod, P. (1997). Bovine blastocyst production in vitro after inhibition of oocyte meiotic resumption for $24 \mathrm{~h}$. J. Reprod. Fertil, 109(2), 355-365. doi: 10.1530/jrf.0.1090355.

López-Saucedo, J., Santiago-Moreno, J., Fierro, R., Izquierdo, D., Coloma, M. A., Catalá, M. G., Jiménez, I., Paramio, M. T. (2013). Fertilization capacity of cryopreserved Iberian ibex epididymal sperm in a heterologous in vitro fertilization assay. Zygote. Cambridge University Press, 23(1), 136-144. doi: 10.1017/S0967199413000518.

Maalouf, W. E., Lee, J.-H., \& Campbell, K. H. S. (2009). Effects of caffeine, cumulus cell removal and aging on polyspermy and embryo development on in vitro matured and fertilized ovine oocytes. Theriogenology, 71(7), 10831092. doi: 10.1016/j.theriogenology.2008.12.001.
Mara, L., Sanna, D., Casu, S., Dattena, M., \& Mayorga Muñoz, I. M. (2014). Blastocyst rate of in vitro embryo production in sheep is affected by season. Reprod. Dom. Anim, 49(4), 37-48. doi: 10.1017/S0967199412000706.

María-Gracia, C., Montserrat, R., Dolors, I., Roser M., Sondes, H., \& María-Teresa, P. (2013). Blastocyst development, MPF activity and ATP content of lamb oocytes supplemented with insulin-transferrinselenium (ITS) and ascorbic acid at IVM. Small Ruminant Res, 112(1-3), 103-107. doi: 10.1016/j.smallrumres.2012.12.007.

Marques, M. G., Nascimento, A. B., Gerger, R. P., Gonçalves, J. S., Coutinho, A. R., \& Simões, R. (2011). Effect of culture media on porcine embryos produced by in vitro fertilization or parthenogenetic activation after oocyte maturation with cycloheximide. Zygote, 19(4), 331-337. doi: 10.1017/S0967199410000614.

Mermillod, P., Tomanek, M., RéJane, M., \& Meijer, L. (2000). High Developmental Competence of Cattle Oocytes Maintained at the Germinal Vesicle Stage for 24 Hours in Culture by Specific Inhibition of MPF Kinase Activity. Mol. Reprod Dev, 55(1), 89-95. doi: 10.1002/(SICI)1098-2795(200001)55:1\%3C89::AIDMRD12\%3E3.0.CO;2-M.

Paramio, M. T., \& Izquierdo, D. (2016). Recent advances in in vitro embryo production in small ruminants. Theriogenology, $\quad 86(1), \quad 152-159$. doi: 10.1016/j.theriogenology.2016.04.027.

Rizos, D., Clemente, M., Bermejo-Alvarez, P., de La Fuente, J., Lonergan, P., \& Gutie'rrez-Ada'n, A. (2008). Consequences of In Vitro Culture Conditions on Embryo Development and Quality. Reprod Dom Anim, 43(4), 44-50. doi: 10.1111/j.14390531.2008.01230.x.

Rose, R. D., Gilchrist, R. B., Kelly, J. M., Thompson, J. G., \& Sutton-McDowall, M. L. (2013). Regulation of sheep oocyte maturation using cAMP modulators. Theriogenology, 564(79), 142-148. doi:10.1016/ j.theriogenology.2012.09.020.

Sadeesh, E. M., Selokar, N. L., Balhara, A. K., \& Yadav, P. S. (2016). Differences in developmental competence and gene expression profiles between buffalo (Bubalus bubalis) preimplantation embryos cultured in three different embryo culture media. Cytotechnology, 68(5), 1973-1986. doi: 10.1007/s10616-016-0010-2.

Saeki, K., Nagao, Y., Kishi, M., \& Nagai, M. (1997). Developmental capacity of bovine oocytes following inhibition of meiotic resumption by cycloheximide or 6 dimethylaminopurine. Theriogenology, 48(7), 11611172. doi: 10.1016/s0093-691x(97)00349-x.

Sasaki, M., Kato, Y., Yamada, H., \& Terada, S. (2005). Development of a novel serum-free freezing medium for mammalian cells using the silk protein sericin. Biotechnol Appl Biochem, 42(2), 183-188. doi: 10.1042/BA20050019.

Schwarzer, C., Esteves, T. C., Arau-Bravo, M. J., Le Gac, S., Nordhoff, V., \& Schlatt, S. (2012). ART culture conditions change the probability of mouse embryo gestation through defined cellular and molecular responses. Hum. Reprod, 27(9), 2627-536 doi: 10.1093/humrep/des223. 
Shi, J. M., Yi, J. Y., Tian, X. Z., Wang, F., Lian, Z. X., Han, H. B., Fu, J. C., Lv, W. F., \& Liu, G. S. (2015). Effects of seasonal changes on the ovulation rate and embryo quality in superovulated Black Suffolk ewes. Neuro Endocrinol Lett. 36(4), 330-336. URL: https://pubmed.ncbi.nlm.nih.gov/26454488.

Shin, H. W. (2016). Animal Models in CRS and Pathophysiologic Insights Gained: A Systematic Review Laryngoscope Investig Otolaryngol, 1(5), 116-123.

Shirazi, A., Ardali, M. A., Ahmadi, E., Nazari, H., Mamuee, M., \& Heidari, B. (2012). The Effect of Macromolecule Source and Type of Media During In vitro Maturation of Sheep Oocytes on Subsequent Embryo Development. J. Reprod. Infertil, 13(1), 13-19. URL: $\quad$ https://www.ncbi.nlm.nih.gov/pmc/articles/ PMC3719375.

Thomas, R. E., Thompson, J. G., Armstrong, D. T., \& Gilchrist, R. B. (2004). Effect of specific phosphodiesterase isoenzyme inhibitors during in vitro maturation of bovine oocytes on meiotic and developmental capacity. Biol. Reprod, 71(1), 11421149 doi: 10.1095/biolreprod.103.024828.

Walker, S. K., Hill, J. L., Kleemann, D. O., \& Nancarrow, C. D. (1996). Development of Ovine Embryos in
Synthetic Oviductal Fluid Containing Amino Acids at Oviductal Fluid Concentrations. Biol Reprod, 55(3), 703-708. doi: 10.1095/biolreprod55.3.703.

Wei, X., Xiaoling, Z., Kai, M., Rui, W., Jing, X., Min, G., Zhonghong, W., Jianhui, T., Xinyu, Z., \& Lei, A. (2016). Characterization and comparative analyses of transcriptomes for in vivo and in vitro produced periimplantation conceptuses and endometria from sheep. J. Reprod. Dev, 62(3), 279-87. doi: 10.1262/jrd.2015-064.

Yasmin, C., Otoi, T., Setiadi, M.A., Karja, N. W. K. (2015). Maturation and fertilization of sheep oocytes cultured in serum-free medium containing silk protein sericin. Acta Vet. Hung, 63(1), 110-117. doi: 10.1556/AVet.2015.009.

Zhang, X, Liu, X., Chen, L., Wu, D.-Y., Nie, Z.-W., Gao, Y.-Y., \& Miao, Y.-L. (2017). Caffeine delays oocyte aging and maintains the quality of aged oocytes safely in mouse. Oncotarget, 8(13), 20602-20611. doi: 10.18632/oncotarget.15292.

Zhu, J., Amarnath, D., Choi, I., Tsunoda, Y., \& Campbell, K. (2015). Demecolcine can overcome rat oocyte spontaneous activation. J. Vet. Sci. Res, 2(1), 1-12. doi: 10.1016/j.ijvsm.2018.02.003. 